\title{
A Qualitative Study on the Outcomes of Social Media Advertising
}

\author{
Shariful Islam ${ }^{1}$, Mohammad Iqbal Mahmood ${ }^{2}$ \\ ${ }^{1}$ School of Journalism and Information Communication, Huazhong University of Science \& Technology, Wuhan, China \\ ${ }^{2}$ Bangladesh University of Professionals (BUP), Dhaka, Bangladesh \\ Email: *imshi8@yahoo.com
}

How to cite this paper: Islam, S., \& Mahmood, M. I. (2018). A Qualitative Study on the Outcomes of Social Media Advertising. Advances in Journalism and Communication, 6, 61-73.

https://doi.org/10.4236/ajc.2018.62006

Received: April 8, 2018

Accepted: June 26, 2018

Published: June 29, 2018

Copyright $\odot 2018$ by authors and Scientific Research Publishing Inc. This work is licensed under the Creative Commons Attribution International License (CC BY 4.0).

http://creativecommons.org/licenses/by/4.0/

\begin{abstract}
In this modern digitalized world, almost everyone is attached with internet. So there is an opportunity for the advertisers to use the social apps/internet for the purpose of advertising. This study was conducted to check the impact of social media advertising on customers' purchase intention while considering the customers' motivation and customers' perception as mediating variables. This is a qualitative study based on the interpretivism philosophy which is conducted on university students in China. The population for this research was the entire students of the university and the data were collected through interviews from 10 respondents. The respondents were the students of different departments of the university owning the smart phones and using Facebook and Instagram. Framework analysis approach was used to see the common responses of students regarding outcomes of social media advertising. The results have indicated that advertising on social media increases customers' motivation and improves perception of the company for viewers which ultimately enhances customers' purchase intention.
\end{abstract}

\section{Keywords}

Social Media, Advertising through Photos, Customers' Motivation, Perception

\section{Introduction}

After the arrival of social media, marketing trends have been entirely changed. Due to this revolution, interactive relations have been developed between firms and their consumers. And it is playing its role to increase the brand awareness among consumers (Radwanick, 2010). To obtain new purchasers and fulfill their needs, social networking appeals are used in ads. It is used to get free advertising by users as well as to get users to share their perception about the brand. Social media advertising contains the strong attraction to be considered as the best tar- 
geted medium for the purpose of advertising which offers the advanced ways and tactics to target the potential and existing customers using social media phones which can never be done through traditional advertising media such as print media, television and radio (Leppaniemi \& Karjaluoto, 2005). So there is a need to investigate the reason(s) to rely on the social media for marketing purposes (Waters, Canfield, Foster, \& Hardy, 2011). Using the apps platforms through smart phones for advertising purposes is less expensive and affordable for small scale businesses as compare to other advertising Medias. Companies either manufacturing concern or services concern have started researches to find the efficiency of digital advertising to enhance their awareness in the general public which generates the positive trend in sales (Johns \& Perrott, 2008).

Consumer decides to purchase a product/service after making the perception about that specific product/service. Consumer perception means that what the consumer thinks about a particular product or brand. The promotional techniques and advertising can affect the consumer perception and the purchase intention but the results can vary depending upon the advertising channel (Elliott \& Speck, 1998). Nokia conducted a study by HPI Research. The results shown that the major market of social media phone users who are the persons from the age group of 16 - 45 years are willing to receive the advertising through social media and they are welcoming this warmly (Leppaniemi \& Karjaluoto, 2005). Before the arrival of smart phones in the open market, social media advertising was made through SMS and there are a huge number of researches showing the customers' willingness to be advertised through their social media phones. However, the trends have been entirely changed with the passage of time. Due to the inventions in the area of information technology, people spend their most of the time while using social media phone apps. As in today's modern world where most of the people are attached with social media through smart phones, tablets and laptops, so it would be a better way to advertise the products on the social media to get the positive purchase intention of the consumers which leads towards an increase in sales due to customers' positive purchase intention.

Previous studies recommended for the brands to provide such platforms for their customers on which they can interact with each other (Rowley, 2004). This would be very helpful for the firms to get knowledge about the consumer perception regarding the brand or product. As advertising media, social media is playing an important role for the advertisers as well as customers to get benefits from others' comments and posts (Cha, 2009). Many firms are inspired by the social media i.e. facebook which can link the internet users in a virtual relationship to get benefit from their likes, shares and comments on different posts which can be useful for their brand (Andriole, 2010).

The information which is available on the social media can be effective for the users who join that particular community and the contents that exist on web pages have the power to influence the consumers' perceptions about the brand (Zhao, Grasmuck, \& Martin, 2008). There are also chances for the advertisers to 
speed up the number of viral messages received by the customers through smart phone apps and social media. By this engagement, consumers will be able to see the images or other contents posted by their social media friends on their profiles (Rodgers, Melioli, Laconi, Bui, \& Chabrol, 2013). Holzner (2008) studied that there are more chances to increase the brand image and the sales of that particular brand through social media when the people consider the groups on different social media platforms as the most reliable source of information.

In the present digital world, the influence of the social media marketing on the motivation, perception and purchase intention of the customers should be studied. It is to be needed to find the impact of social media advertising such as apps platforms on consumers' perceptions and motivation which will influence the purchase intention of the customers. This is beneficial to draw a model for social media advertising that demonstrates the vibrant linkage between consumer purchase intention and social media advertising through smart phone apps by taking the mediating effects of motivation and consumers perception about the brand (Dehghani \& Tumer, 2015). Our study is a step forward towards the understanding of the consumers' purchase intention to adopt the brands through social media advertising by using social media or social media apps. This paper primarily focuses on the impacts of social media advertising while examining the relationships among customer perception, motivation and purchase intention. The research question of this study is as follows:

Is there a positive impact of social media advertising on customers' purchase intention?

\section{Literature Review}

\subsection{Social Media Advertising}

The market of smart phones is increasing day by day. It is estimated that there are roughly 2 billion smart phone users in the market (1.91 billion to be exact) till Oct 13, 2015, with that number expected to increase another 12\% in 2016 to top 2.16 billion people globally (Kissonergis, n.d.). Social media advertising will clearly become more relevant in the coming years as analysts' estimates reveal (Leppaniemi \& Karjaluoto, 2005). Social media advertising means to use the social media phones for the purpose of advertising. There are various definitions of social media advertising in different academic and industrial publications. The Social media Marketing Association, the worldwide leader in promoting social media marketing via social media devices, defines m-marketing as the use of the social media medium as a communications and entertainment channel between a brand and an end-user (Fornell \& Larcker, 1981). After the introduction of multi touch screen social media phones in 2007, a number of people adopted the smart phones though out the world. There is an increasing trend of smart phone usage as most of the retailers are receiving more than $50 \%$ of the online traffic from the smart phones instead of computers or laptops. Google play and Apple App store's statistics show that the number of downloads through smart phones 
is more than 135 billion and is expected to cross 268 billion till 2017. Social media users spend more than half of their media usage time on social media apps. In simple words we can say that people are addicted of social media apps.

Through social media apps users are able to perform a number of tasks like searching, retrieving and sharing the information, bill payment, map navigation and to make purchases. Due to the high customer involvement in social media apps, many companies have developed their smart phone apps to communicate and advertise their products to their customers (Kim, Wang, \& Malthouse, 2015). About $60 \%$ of smart phone owners have encountered smart phone advertising while $69.5 \%$ have viewed smart phone advertisements, and $62.3 \%$ have purchased advertised products or services (Kim \& Han, 2014). By considering above phenomenon, it can be concluded that the customer are highly attached with social media through smart phone apps. So platform of social media apps can be a good place for advertising the brands. As there is a great number of people having smart phones so there are high chances to target the high number of people through social media apps. There will be an increasing trend of social media apps advertising in the coming years due to increase in the number of smart phone users which indicates the opportunity for the organizations to retain the current customers as well as to attract the potential customers with through apps advertising which as in inexpensive and efficient way to aware the customers.

\subsection{Customer Perception}

Customer perception is difficult, complex and dynamic to define (Issanchou, 1996). However, we can say that customer perception is a marketing concept which means a customer's impression, awareness or consciousness about a company or its products/services. Kazmi (2012) defined the perception as it is how a human recognize and interpret stimuli. In other words we can say that perception is the very first impression which is drawn by a person and on the basis of this impression, he/she selects and interprets the information to shape a meaningful image of the world (Munnukka, 2008). Due to this, it is believed that customer perception influences the purchase intention of the customer. It can be affected by advertising, reviews, public relations, social media, personal experiences and other channels. In this era when smart phone users have a large number, there can be positive impact on customer perception about the company through advertising on social media phones. Awareness plays an important role to generate a positive customer perception about the company/brand which leads towards the purchase intention and the awareness can be created by advertisement and media (Aaker \& Joachimsthaler, 2000). Customer perception and the purchase intention can be interdependent on each other; customer perception can be affected by purchase intention (Nandagopal \& Chinnaiyan, 2003). As these variables are interdependent so the customer purchase intention also be stimulated be customer perception about that specific product. Customer perceptions are not fixed i.e. Perceptions do not remain same all the time. These can 
be changed (Köster, Mojet, Frewer, Trijp, \& others, 2006). It means that advertising may play its role to change the perceptions of the customers about the company/brand. We can say that advertisement is the driving force (Akaka \& Alden, 2010), which have the power to shape customer perceptions. The selection of media for the purpose of advertising is a sensitive process as it leaves its impact on customer perception which drives towards the purchase intention. So it is necessary to choose the right media for the advertisement as type of media used for advertising influences the customer perceptions (Liligeto, Singh, \& Naz, 2014). Through cognition, advertising plays its role to shape the consumer behavior. Cognition is the perception of an individual which is communicated through advertising. To observe these cognitions; customer perception, senses and attention are used by an individual (Jakštienè, Susnienè, \& Narbutas, 2008).

\subsection{Customer Motivation}

Motivation is a condition when person encourages the desire of individuals to undertake activities to achieve a goal (Setiadi, 2003). (Dharmestha \& Handoko, 2008) said that motivation is the needs and desires of individuals are directed on purpose to obtain satisfaction. Internal and external factors influence the customers' purchase process. Psychological motivation works as a stimulator to drive the customers' behavior to go to the store for the purchase which will fulfill their need (Kim \& Jin, 2001). Motivations for purchase were firstly studied by (Tauber, 1972). He proposed that customers are motivated for buying due to several psychosocial motives. These can be divided into personal motives including entertainment, physical activity, learning about new trends and the social motives include social past experience, communication, social status, authority, and pleasure of bargaining (Tauber, 1972). Celsi \& Olson (1988) suggested that there is a positive relationship between motivation and advertisement. Customers having high level of motivation will watch the advertising with more devotion. Advertisements are equipped with emotional and rational appeals. These appeals work as an arousal to motivate the customers psychologically to purchase the products. Advertisement influences the customers to motivate them to buy a particular product/service and it can make or change the perception of a customer about that particular product/service (Fatima \& Lodhi, 2015). Advertising plays an important role to shape the customers' buying behavior and work as a source of motivation which enforce the customer to purchase that particular product/service which was shown in the advertising (Rai, 2013). Customer behaviors are shaped and they are motivated to purchase a particular product/service with the help of advertising. Previous studies proposed that the advertisements are the source of motivation for the customers which help them to remember the product/service and purchase it repeatedly by hitting their minds (Pope, Voges, \& Brown, 2009). It means that there is a direct relationship between advertising, advertising media and the customer motivation. And this motivation works as a stimulus which leads the customer towards making buying decision. 


\subsection{Purchase Intention}

Purchase intention can be defined as a customer's perception to purchase a particular product and/or service. Keller (2001) suggested that there are many factors (internal and/or external) which can have their impact of the customers' purchase intention. There are several internationally conducted studies on various factors influencing purchase intention but no one has studied the impact of social media advertising on the purchase intention. Based on the study of (Dehghani \& Tumer, 2015) social media advertising, customer perception and customer motivation are the factors which can influence the customers' purchase intention. It is difficult and complex to study the customer's purchase decision(s). Purchase intention is normally backed by customer perception. Purchase behavior is an important factor to evaluate a specific product/brand (Keller, 2001). Purchase intention is an efficient tool to predict the customers' buying decisions (Jayanti \& Ghosh, 1996). Purchase intentions drive the customers when they decide to buy a specific product(s). Customers normally like to buy the well reputed and familiar products; which is because of the brand awareness created by advertising (Keller, 1993; Macdonald \& Sharp, 2000). Purchase intention can be divided into three categories including "unplanned buying", "partially planned buying", "fully planned buying". When a customer makes the decision to buy a specific product in the store, it is the "unplanned buying", it can also be called the "impulse buying behavior". In case of "partially planned behavior" customer decide about the product category before going to the store and the brand of that product category is decided inside the store. When a customer decides about the products' specifications, category and brand before going to the store then it is the "fully planned behavior" (Engel, Blackwell, \& Miniard, 1995). The customer purchase intention about a brand which is well known is high as compare to another brand which is not much known (Dodds, Monroe, \& Grewal, 1991; Grewal, Krishnan, Baker, \& Borin, 1998; Hsu, 2000) proposed that a well known brand will also have the high market share as compare to a brand which is less known. Due to the familiarity with a product, customer will have a greater purchase intention for that particular product (Kamins \& Marks, 1991). As much the customer encountered with the advertising of a product, he/she will become more familiar with that particular product. Consumers are affected by brand familiarity when they make their perception to purchase a particular product/service (Alba \& Hutchinson, 2000). It indicates that advertising is a key player which can build the brand familiarity into the prospects' minds that works as a stimulus to make the purchase intentions about that product/service with which a customer is familiar.

\section{Proposed Model and Hypotheses Development}

On the basis of the previous literature review discussed above, the conceptual framework and the hypotheses for this study are developed in this portion. To study the impact of social media advertising on the customer purchase intention, 
customer motivation and customer perception are considered. The different items to measure the above said variables were adopted by (Sinkovics, Pezderka, Haghirian, \& others, 2012; Wang \& Sun, 2010; Xu, Liao, \& Li, 2008: p. 20). The hypotheses of our research are as follows;

H1: "Social media advertising has a positive impact on customer motivation."

H2: "Social media advertising has a positive impact on customer perception."

H3: "Customer motivation has a positive impact on customers' purchase intention."

H4: "Customer perception has a positive impact on customers' purchase intention."

H5: "Social media advertising has a positive impact on customers' purchase intention."

These hypotheses have been checked through the interviews and framework analysis approach. If the arguments of the students will be in consensus regarding these hypotheses then they will be accepted, otherwise hypotheses will be rejected (Figure 1).

\section{Methodology}

Our study is based on interpretivism philosophy and the results of the study are derived from real fact and figures and sensory experience. This is a qualitative cross sectional study by nature as data was collected only for one time. The research was conducted in a public university of China. And the data was collected by the students of the university. The respondents of our study are the under graduate and post graduate students. They were in different years of their education and from different fields of study i.e. business administration, commerce, information technology and law etc. We selected this organization for the data collection because majority of that population own the smart phones and they are familiar with social media phone apps. As we have collected the data from university students so by using the inductive approach, we can be able to generalize our results to the whole population of the country which is using the smart phone apps. The data was collected from a 10 respondents through interviews. Those 10 respondents have been selected randomly through purposive sampling technique but to assure the representativeness of the sample, one student from each department has been selected. Following questions have been asked in interviews:

1) Do you think that social media advertisement is effective for customers?

2) What sort of feelings you experience after seeing advertisement on social media?

3) How your purchase pattern develops through social media advertisement?

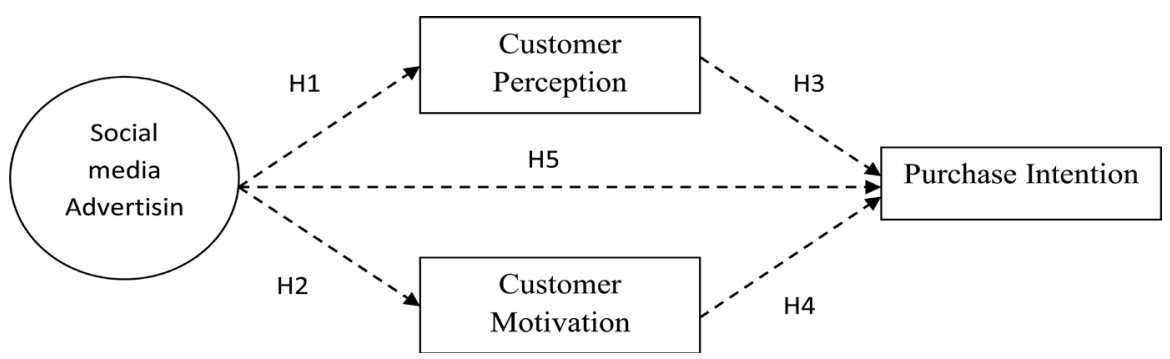

Figure 1. Conceptual framework. 
Table 1. Framework analysis.

4) Either there is any role of motivation and perceptions of customers in developing purchase intention?

5) Why social media advertisements are better than traditional media advertisements?

Framework analysis approach has been utilized in this research study which is one of the most renowned qualitative data analyses techniques. In this technique, data obtained from the interviews have been classified in consensus and opposite responses to compare that how much students of different departments have been agreed on the impacts of social media advertisement on customers and to analyze the degree to which they think in contrast to each other. The same thing has been repeated for all other questions which have been asked in the interviews.

\section{Respondents' Profiles}

The data was collected from 10 respondents. From which 50\% were male and $50 \%$ were female respondents. Most of the respondents were from the age group between 18 - 25 years. About $62.3 \%$ of the respondents were the undergraduates or less and remaining $37.7 \%$ were the post graduate students.

\section{Results and Analysis}

Framework analysis approach is one of the most popular approaches among qualitative analysis approaches. In this analysis, researcher analyzes the common and consensus responses of interviewees and tries to develop his or her understanding on the basis of those mutual responses. Following is Table 1 in which framework analysis has been done.

\begin{tabular}{|c|c|c|}
\hline Framework Part & Consensus Response & Opposite View \\
\hline $\begin{array}{l}\text { Effectiveness of } \\
\text { Social Media } \\
\text { Advertisement }\end{array}$ & $\begin{array}{l}\text { Most of the respondents found agreed on the fact that social media } \\
\text { advertisements are effective as they are portraying the detailed and real } \\
\text { picture of the product or organization to bulk of people with minimal cost. }\end{array}$ & $\begin{array}{l}\text { Very Few respondents have also shown disagreement as } \\
\text { they argued that many times undesired ads are } \\
\text { broadcasted on social media which creates the emotions of } \\
\text { anger. }\end{array}$ \\
\hline $\begin{array}{l}\text { Experience about } \\
\text { Social Media } \\
\text { Advertisement }\end{array}$ & $\begin{array}{l}\text { Almost all respondents have confirmed that social media advertisements } \\
\text { have motivated them to shop those things which they have not previously } \\
\text { done. For an instance, most of them quoted the ads of Ali Baba on Facebook } \\
\text { which has motivated most of them to become a supplier or buyer at same } \\
\text { platform. }\end{array}$ & $\begin{array}{l}\text { Rare respondents have indicated that imaginary and } \\
\text { artificial products shown on ads have deceived them in } \\
\text { their shopping experience so their experience is not good } \\
\text { about Social Media ads. }\end{array}$ \\
\hline $\begin{array}{l}\text { Development of } \\
\text { Purchase } \\
\text { Intention }\end{array}$ & $\begin{array}{l}\text { Respondents have specifically quoted the incidents in which social media and } \\
\text { its ads have persuaded them to purchase some commodities. }\end{array}$ & $\begin{array}{l}\text { Some respondents said that although most of the ads on } \\
\text { social media enhance purchase intention still there are } \\
\text { some ads of unwanted products which also reduce } \\
\text { purchase intention for such products. }\end{array}$ \\
\hline $\begin{array}{l}\text { Motivation and } \\
\text { Perception } \\
\text { Change }\end{array}$ & $\begin{array}{l}\text { Respondents have unanimously shown their consent that motivation and } \\
\text { perception bridge the way between social media ads and purchase intention. } \\
\text { Few students from marketing background also gave reference of AIDA model } \\
\text { in which they exhibit that interest creates motivation and makes the } \\
\text { perception better resulting in ultimate purchase. }\end{array}$ & $\begin{array}{l}\text { Few respondents said that sometimes increased } \\
\text { motivation and positive perception do not sustain till the } \\
\text { ultimate purchase mostly because of purchasing power } \\
\text { differences. }\end{array}$ \\
\hline $\begin{array}{l}\text { Comparison with } \\
\text { Traditional } \\
\text { Advertisements }\end{array}$ & $\begin{array}{l}\text { All respondents have voted in favor of social media ads that they are far } \\
\text { better than traditional media ads. }\end{array}$ & $-\cdots-$ \\
\hline
\end{tabular}


The above mentioned framework has presented 5 major themes on which agreed and contrast opinions have been discussed. Following are those 5 themes and their analyses:

- Effectiveness of Social Media Advertisement: Most of the respondents have confirmed this hypothesis as social media targets bulk of consumers or customers in one go and it is not hard for such rapid digital technology to access millions of customers around the world. Disagreement which was given in this regard was just based on non-intended ads but gradually some platforms like Google are trying to make the experience of a user filtered by eliminating such ads.

- Experience about Social Media Advertisement: As it was expected, most of the respondents quoted some B2B and B2C suppliers whose ads are attractive enough to convince them to buy certain things which were not previously in their shopping list. However, discrepancy of the products from their real form to the form which has been shown in the ads has also witnessed some negative experiences. Such customers have to choose their brand quite critically to avoid from such deception.

- Development of Purchase Intention: Interview results have shown that it has happened with them for a lot of time that their purchase intention stimulates after seeing ads on social media. This is not just because of attractiveness of the ad but also because of the door step availability of such distanced products.

- Motivation and Perception Change: Respondents believe that the AIDA model which is being used in ads is attracting a lot of interest in products and ultimately persuading a reaction for final purchase.

\section{Discussions and Conclusion}

As the advertising on social media has a factor of interactivity for the users/customers i.e. advertising through social apps. The results of the present study are indicating that people find the apps advertising are informative, personalized, entertaining, and attractive and help them to make the decision for purchase of that particular product. The results show that there is a significant relationship between Social media Advertising and Purchase Intention of the customers with the mediating effects of Customer Motivation and Customer Perception. So it can be concluded that the advertising through social apps/Social media Advertising has the attractiveness for the customers which is a source of motivation for the customer to decide to purchase the product after watching the advertising on the social app(s). Now the advertising trends have been changed totally. It is the era of interactive and trust based advertising so the advertisers should focus to increase their social medial advertising budget to get the advantage of the changing trends of the customers of $21^{\text {st }}$ century. The companies can remain in touch with their worthy customers with the help of social media phone apps/social media advertising. It will enable them to get the feedback from the 
customers and offer them after sale services to get them highly motivated towards that particular brand which will generate the positive customer perceptions about the company and so they will make the decisions to purchase that product again and again. The respondents also stated that they make the perception about the brand when people on the social apps talk about a particular product on social media and react on them. It is vital for the companies to go for the relationship marketing to survive in the present market conditions of high competition. Social media Advertising provides a platform to the companies to get their worthy customer at one platform and maintains a long term and trusty relationship with them by providing values according to their needs and wants. The results of this study can provide the guidelines to the advertisers/companies to design their advertising plan while considering the apps platform as a major medium for the advertising to interact with their customers globally.

There are some of the limitations of the present research. First one is the time limitation as the researcher has a confined time to complete all the proceedings so this research has been made vast and focused by realizing that time limitation, second is that we cannot generalize the results of the study in which sample size was only 10 from the university students only. There are the other users of the social apps which are not the university students so in the future studies the data should also be collected from other types of the sampling units. The sample size for the study should also be increased according to the population of the smart phone users.

\section{References}

Aaker, D. A., \& Joachimsthaler, E. (2000). Brand Leadership: The Next Level of the Brand Revolution. New York: The Free Press.

Akaka, M. A., \& Alden, D. L. (2010). Global Brand Positioning and Perceptions: International Advertising and Global Consumer Culture. International Journal of Advertising, 29, 37-56. https://doi.org/10.2501/S0265048709201026

Alba, J. W., \& Hutchinson, J. W. (2000). Knowledge Calibration: What Consumers Know and What They Think They Know. Journal of Consumer Research, 27, 123-156. https://doi.org/10.1086/314317

Andriole, S. J. (2010). Business Impact of Web 2.0 Technologies. Communications of the ACM, 53, 67. https://doi.org/10.1145/1859204.1859225

Celsi, R. L., \& Olson, J. C. (1988). The Role of Involvement in Attention and Comprehension Processes. Journal of Consumer Research, 15, 210-224.

https://doi.org/10.1086/209158

Cha, J. (2009). Shopping on Social Networking Web Sites: Attitudes toward Real versus Virtual Items. Journal of Interactive Advertising, 10, 77-93. https://doi.org/10.1080/15252019.2009.10722164

Dehghani, M., \& Tumer, M. (2015). A Research on Effectiveness of Facebook Advertising on Enhancing Purchase Intention of Consumers. Computers in Human Behavior, 49, 597-600. https://doi.org/10.1016/j.chb.2015.03.051

Dharmestha, S. B., \& Handoko, T. H. (2008). Manajemen Pemasaran, Analisa Perilaku Konsumen, edisi pertama, cetakan keempat. Yogyakarta: BPFE. 
Dodds, W. B., Monroe, K. B., \& Grewal, D. (1991). Effects of Price, Brand, and Store Information on Buyers' Product Evaluations. Journal of Marketing Research, 28, 307-319. https://doi.org/10.2307/3172866

Elliott, M. T., \& Speck, P. S. (1998). Consumer Perceptions of Advertising Clutter and Its Impact across Various Media. Journal of Advertising Research, 38, 29-30.

Engel, J. F., Blackwell, R. D., \& Miniard, P. W. (1995). Consumer Behavior (8th eds.). New York: The Dryden Press.

Fatima, S., \& Lodhi, S. (2015). Impact of Advertisement on Buying Behaviours of the Consumers: Study of Cosmetic Industry in Karachi City. International Journal of Management Sciences and Business Research.

http://papers.ssrn.com/sol3/papers.cfm?abstract_id=2740920

Fornell, C., \& Larcker, D. F. (1981). Evaluating Structural Equation Models with Unobservable Variables and Measurement Error. Journal of Marketing Research, 18, 39-50. https://doi.org/10.2307/3151312

Grewal, D., Krishnan, R., Baker, J., \& Borin, N. (1998). The Effect of Store Name, Brand Name and Price Discounts on Consumers' Evaluations and Purchase Intentions. Journal of Retailing, 74, 331-352. https://doi.org/10.1016/S0022-4359(99)80099-2

Holzner, S. (2008). Facebook Marketing: Leverage Social Media to Grow Your Business. London: Pearson Education.

Hsu, Y. Y. (2000). The Impact of Brand Awareness, Reference Price, Product Knowledge and Product Characteristics on Brand Evaluation and Consumers' Purchase Intention. Unpublished Master Thesis, Tainan: National Cheng Kung University.

Issanchou, S. (1996). Consumer Expectations and Perceptions of Meat and Meat Product Quality. Meat Science, 43, 5-19. https://doi.org/10.1016/0309-1740(96)00051-4

Jakštienė, S., Susnienė, D., \& Narbutas, V. (2008). Increasing the Opportunities of the Internet as a Contemporary Advertising Medium. Socialiniai Tyrimai, 2008, 63-70. http://search.ebscohost.com/login.aspx?direct=true\&profile=ehost\&scope=site\&authty pe $=$ crawler \&jrnl $=13923110 \& A N=37376220 \& \mathrm{~h}=\mathrm{jc} 0 \mathrm{O} \% 2 \mathrm{BhWGau} 1 \mathrm{Zy} 1 \mathrm{wUx} \% 2 \mathrm{Ba} 92 \mathrm{w}$ Z\%2FNVIvCi0jmLdOJ6TSQNfST67eLRaUfds9t8D4GCAfBzNJN1QY6O\%2FNyygyX7 qPA\%3D\%3D\&crl=c

Jayanti, R. K., \& Ghosh, A. K. (1996). Service Value Determination: An Integrative Perspective. Journal of Hospitality \& Leisure Marketing, 3, 5-25. https://doi.org/10.1300/J150v03n04_02

Johns, R., \& Perrott, B. (2008). The Impact of Internet Banking on Business-Customer Relationships (Are You Being Self-Served?). International Journal of Bank Marketing, 26, 465-482. https://doi.org/10.1108/02652320810913846

Kamins, M. A., \& Marks, L. J. (1991). The Perception of Kosher as a Third Party Certification Claim in Advertising for Familiar and Unfamiliar Brands. Journal of the Academy of Marketing Science, 19, 177-185. https://doi.org/10.1007/BF02726494

Kazmi, S. Q. (2012). Consumer Perception and Buying Decisions (The Pasta Study). International Journal of Advancements in Research \& Technology, 1, 123-132.

Keller, K. L. (1993). Conceptualizing, Measuring, and Managing Customer-Based Brand Equity. The Journal of Marketing, 57, 1-22. https://doi.org/10.2307/1252054

Keller, K. L. (2001). Building Customer-Based Brand Equity: A Blueprint for Creating Strong Brands.

http://www.academia.edu/download/40863813/CustomerBasedbrandEquityModel.pdf

Kim, S. J., Wang, R. J.-H., \& Malthouse, E. C. (2015). The Effects of Adopting and Using a Brand's Social Media Application on Customers' Subsequent Purchase Behavior. Jour- 
nal of Interactive Marketing, 31, 28-41. https://doi.org/10.1016/j.intmar.2015.05.004

Kim, Y. J., \& Han, J. (2014). Why Smartphone Advertising Attracts Customers: A Model of Web Advertising, Flow, and Personalization. Computers in Human Behavior, 33, 256-269. https://doi.org/10.1016/j.chb.2014.01.015

Kissonergis, P. (n.d.). Smartphone Ownership, Usage and Penetration by Country. http://thehub.smsglobal.com/smartphone-ownership-usage-and-penetration

Köster, E. P., Mojet, J., Frewer, L., van Trijp, H. et al. (2006). Theories of Food Choice Development. In L. Frewer, \& H. C. M. Van Trijp (Eds.), Understanding Consumers of Food Products (pp. 93-124). Abington, Cambridge: Woodhead Publishing.

Leppaniemi, M., \& Karjaluoto, H. (2005). Factors Influencing Consumers' Willingness to Accept Social Media Advertising: A Conceptual Model. International Journal of Social media Communications, 3, 197-213.

Liligeto, R., Singh, G., \& Naz, R. (2014). Factors Influencing Consumer Perception (CP) towards TV and Newspaper Advertising. Journal of Pacific Studies, 34, 63-86.

Macdonald, E. K., \& Sharp, B. M. (2000). Brand Awareness Effects on Consumer Decision Making for a Common, Repeat Purchase Product: A Replication. Journal of Business Research, 48, 5-15. https://doi.org/10.1016/S0148-2963(98)00070-8

Munnukka, J. (2008). Customers' Purchase Intentions as a Reflection of Price Perception. Journal of Product \& Brand Management, 17, 188-196.

https://doi.org/10.1108/10610420810875106

Nandagopal, R., \& Chinnaiyan, P. (2003). Brand Preference of Soft Drinks in Rural Tamil Nadu. Indian Journal of Marketing, 33, 14-17.

Ok Kim, J., \& Jin, B. (2001). Korean Consumers' Patronage of Discount Stores: Domestic vs. Multinational Discount Store Shoppers' Profiles. Journal of Consumer Marketing, 18, 236-255. https://doi.org/10.1108/07363760110393092

Pope, N., Voges, K. E., \& Brown, M. (2009). Winning Ways. Journal of Advertising, 38, 5-20. https://doi.org/10.2753/JOA0091-3367380201

Radwanick, S. (2010). The 2009 Us Digital Year in Review. Http://www.Comscore.Com/index.php/Press_Events/Press_Releases/2010/2/comScore _Releases_2009_U.S._Digital_Year_in_Review http://www.smama.ch/wp-content/uploads/2012/05/09_US_Digital_Year_in_Review_c omScore_e1.pdf

Rai, N. (2013). Impact of Advertising on Consumer Behaviour and Attitude with Reference to Consumer Durables. International Journal of Management Research and Business Strategy, 2, 2-8.

Rodgers, R. F., Melioli, T., Laconi, S., Bui, E., \& Chabrol, H. (2013). Internet Addiction Symptoms, Disordered Eating, and Body Image Avoidance. Cyberpsychology, Behavior, and Social Networking, 16, 56-60. https://doi.org/10.1089/cyber.2012.1570

Rowley, J. (2004). Just Another Channel? Marketing Communications in e-Business. Marketing Intelligence \& Planning, 22, 24-41. https://doi.org/10.1108/02634500410516896

Setiadi, N. J. (2003). Prilaku Konsumen, Jakarta. Prenada Media.

Sinkovics, R. R., Pezderka, N., Haghirian, P. et al. (2012). Determinants of Consumer Perceptions toward Social Media Advertising-A Comparison between Japan and Austria. Journal of Interactive Marketing, 26, 21-32.

https://doi.org/10.1016/j.intmar.2011.07.002

Tauber, E. M. (1972). Why Do People Shop? The Journal of Marketing, 36, 46-49. https://doi.org/10.2307/1250426 
Wang, Y., \& Sun, S. (2010). Assessing Beliefs, Attitudes, and Behavioral Responses toward Online Advertising in Three Countries. International Business Review, 19, 333-344. https://doi.org/10.1016/j.ibusrev.2010.01.004

Waters, R. D., Canfield, R. R., Foster, J. M., \& Hardy, E. E. (2011). Applying the Dialogic Theory to Social Networking Sites: Examining How University Health Centers Convey Health Messages on Facebook. Journal of Social Marketing, 1, 211-227. https://doi.org/10.1108/20426761111170713

Xu, D. J., Liao, S. S., \& Li, Q. (2008). Combining Empirical Experimentation and Modeling Techniques: A Design Research Approach for Personalized Social Media Advertising Applications. Decision Support Systems, 44, 710-724.

https://doi.org/10.1016/j.dss.2007.10.002

Zhao, S., Grasmuck, S., \& Martin, J. (2008). Identity Construction on Facebook: Digital Empowerment in Anchored Relationships. Computers in Human Behavior, 24, 1816-1836. https://doi.org/10.1016/j.chb.2008.02.012 